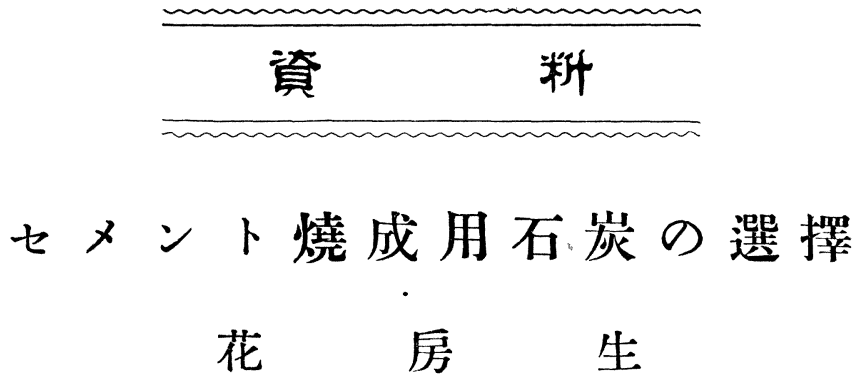

I 緒言

セメントエ業に於ける然料の問題は極めて重大な項目であつて、現在の最も進步した工場でも セメント $1,000 \mathrm{~kg}$ 燒成するのに、乾式でば約 $300 \mathrm{~kg}$ 、濕式では約 $400 \mathrm{~kg}$ の石炭を要し、製造費 の 1 割 5 分乃至 2 割 5 分を占める物である。

近來熱效率良を窯つ設計とか、廢熱の利用とか言ふ方面には長足の發達を示して居るが、此等 機械的發展と相關連して。より根本的な燃料の本質（本題では石炭に就てのみ記述する）に關す

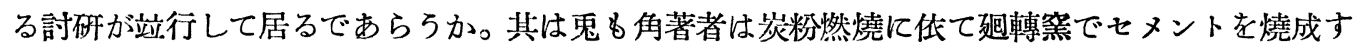
る場合に如何なる石炭を使用するが最も有利なるかの問題に就て平素考へる所を述べ、識者の御 叱正を得ん事を望む。

ミーデェ氏 (Meade, Portland, Cement.) はセメント燒成用炭として

第一表

$\begin{array}{ll}\text { 揮 發分 } & 30 \sim 45 \% \\ \text { 固定孷素 } & 49 \sim 60 \% \\ \text { 兏分 (價格のゆろす限り少量なろ事) } & 25 \% \text { 以下 }\end{array}$

硫黄（黃鐵鉞として混ずろ時は不可なれど狳り多量てなければ差支えなし）

上記の如き長焰炭を推薦して居る。

最近モルチェ氏（O. V. Morch, Transactions of tbe Fuel Conference, London. 1928) はセメ ント工業に於ける燃料問題を論ずる際に使用石炭の品質に言及し、揮發分 25〜35\%を含有する 瀝青炭が適當であるが、揮發分 $15 \%$ のものも使用可能であり、無煙炭・骹炭・牛骹炭の混用亦 妨げなく、獨逸では褐炭を使用して居り、泥炭の混用も聞く所である。灰分は $25 \%$ 何下をよし とすと述べて居る。

同年ブライス氏 (E. K. Blythe) ๖第二包萬國瀝青炭會議の席上でセメントエ業には長焻式バ ーナーを採用して成功して居る旨の發表あり。

=ールゼン氏 (Harald Nielsen, Iron Coal Trades Rev., 1926)は炭粉燃燒汽罐用炭に就て論述 し揮發分 $12 \%$ 以上の石炭が適當であるが、粉碎に餘り動力を要せぬ牛䯚炭にあつては極微に粉: 
碎すれば揮發分 $10 \%$ 位の物でも有利に使用出來、試用に依て燃燒室の清澄な事、豫想以上長焰 であつた事、過剩空氣少量でよい事等を報じ、何燃燒生成瓦斯の容量少量なる䉆燃燒室が小さく て可なりと諭じて居る。

以上文獻に依て炭粉燃燒用には無煙炭、瀝青炭は勿諭褐炭汁炭等の使用し居る事を見る。斯く 適應性に富むが故に往及炭程の迩定を全然沒却される事があるが此は甚しい誤で、本邦の如く比 較的塽少な地域から各種の石炭を產出する所では最適品選擇の可能性が充分にあり、又同一炭垸 よりの不岑でも上層、下層丈は塊、粉の差造により優劣、有利不利の差の生ずる物である。本文

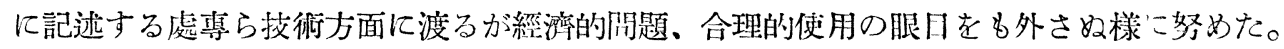

\section{II セメント燒成の特性}

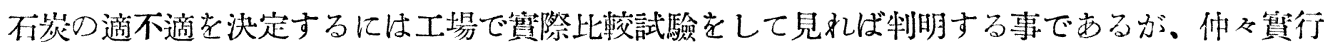
不可能であるから先づ論理的にセメント烍成に特種を條件を調枯し、此の要求に適合する不桨は

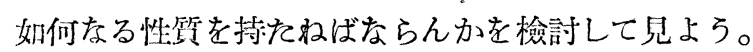

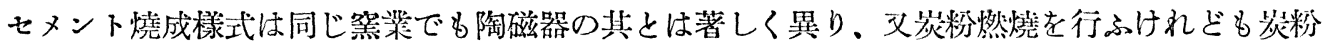

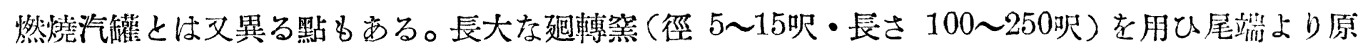
料を送入し、他端より炭粉を吹込み徐ふに前進して來る原料を燒成する（第一閫參澹）のである が、炭粉製造。然燒にあたつて特異㐋る點を次に列舉すると

(1) 多量の石炭を機械的に處理する事

(2) 乾燥をする事

(3) 微粉碎克行ふ事

(4) 吹込み燃燒老行京事

(5) 高溫度に燃燒する必要ある事

（6）石炭灰分の一部は製品中に混融する事

（7）廢熱利用汽罐を附隨する事（なき場合もあり）

（8）飛塵捕集裝置を有する場合ある事

（9）自然發火の災害を蒙る懽むる事

以上九箇條何れも滿足な解決を與へる石炭を以て最良とするに誰しも異存は無いと思ふ。

\section{III 特性に適應すべき石炭の性質}

前項特性中(1)，(2)，(3) は主として石炭の形狀及水分に關する事で。(4)，(5) は化學的の性 質及發熱量に關係し、(6)，(7)，(8) は石炭灰分に關し。(9)は自然性に關する事項である。故に 本項に於ては此の四題目を揭げてセメント燒成用適合炭を吟味する事にする。 
(i) 形狀及び水分

形狀 石炭は粒の大きさに依て通常塊炭・切込炭・粉炭・微粉炭等に分類せられるが、今此の 一例に就て、濕炭一玙當り・乾炭の一カロリー當・水分乾燥用石炭产引きたる一カロリ一當り (仕上げ價格)の價格を比較して見る。

第 二 表

炭種別價格比較表

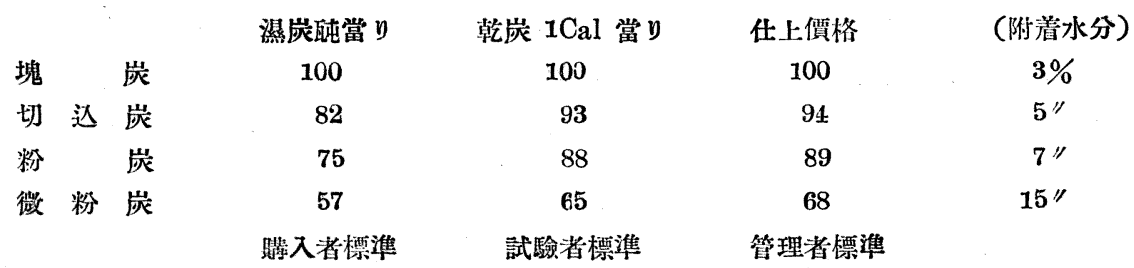

第二表で塊炭が最も高價で漸次粉となる程安價となり微粉炭に於て特に格安である事が分かる。 偖てセメント工場で使用する場合を考へると、取扱の點よりは塊炭最もよく漸次粉となる程水分 もあつて眝槽から取り出す際、輸揆の際各所に附着したり塞つたりして困る。然し此れは設計に 依ては防ぎ得る事であり、乾燥後は消隇する問題である。然るに吹达炭は必和微粉碎して使用す るのであるから、安價粉炭、微粉炭を使用せぬ将をらん。此處に一言附加へたきは第二表の湜 炭玙當り價格は購大者の標準となり、乾炭 $1 \mathrm{Cal}$ 當り價格は試驗者の標準となり、仕上げ價格が 使用者乃至は工場管理者の標淮となるのであるが、此の間には甚だしい價值の相達がある、石炭 を購入する場合は仕上げ價格まで考虑して引合すべきである。

水分 石炭の水分住（イ）附着水分 (口) 濕分 (八) 化合水分の三つに分けて若へる。附着水 分は探掘、撰炭、運搬、貯藏の狀況に低つて變化するが、 $1 \mathrm{~kg}$ の水を乾燥するには $640 \mathrm{Cal}$ の熱 在要するから $10 \%$ の水分を含有する石炭は $1 \mathrm{~kg}$ 當り $64 \mathrm{Cal}$ だけ熱量を損失する事になる。向 實際の場合蒸氣は過熱せられるので損失はてれ以上に達する。

濕分は各種石炭に夫ょ涯ら゙一定で空氣乾燥後 $105^{\circ} \mathrm{C}$ 几熱すると放出するが、伊木氏（土業化 學會誌 昭和三年) に依れば不粘結性で、ウルミン及 $\alpha \beta$ 化合物の多い石炭即山形、宇部、豐國 赤池等の諸炭に多く、三池、夕張等に少いとの事である。

化合水分は乾燥に依ては放出されず、乾餾若くは祭燒した際に生ずる、アンーブス試驗器（全 國石炭分析表 內藤然料硎究所)に依れば此の水分まで檢定出來る、本器に依る成績でも例木氏 の結果と医が同樣で $5 \%$ 以內の物に高島・三池・長城等西り $20 \sim 25 \%$ ののに入山・宇部・荻 城・會寧等がある。

附着水分多き石炭には乾燥費を多額に要するが第二表に見る樣に粉炭及微粉炭は乾燥費を計上 するも何安價となる故之は左程有害の物では無い、然し化合水分の餘りに多量な場合は燃燒溫度 
を低下させる懼がある（詳細は後述）。

(ii) 石炭の化學的性質及び發熱量

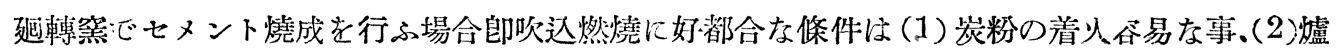
內が漓澄で燃焼帶までよく見通せる事。(3)燃燒帶に熱が集中する事。(4)過剩空莱少なく然も完全

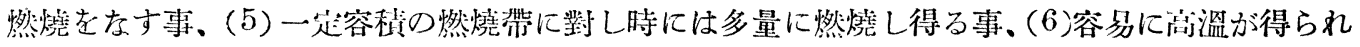
る事等である。

着火の難易は石炭中の描發分に關係し、焎煙炭にあつては着火に相當の困難を感ずる。然しセ

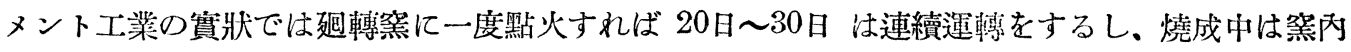
の溫度は $1400 \sim 1600^{\circ} \mathrm{C}$ あるから此の點走餘り心配する事は㶵用である。佮揮發分の少量な場合 には燃燒點が吹达口より遠くなつて羔の有效範園を短縮する。ミーデェ氏、モルチェ氏（緒言參 照)が揮發分を重大視した所以も此等の點にあるが、第一要件とする程の物でもなくニールゼン 氏の說は傾聽に值する。要は揮發分 $10 \%$ 以上の石炭は有利に使用し得る可能性ありと言ひ得る ことである(使用法後述)。

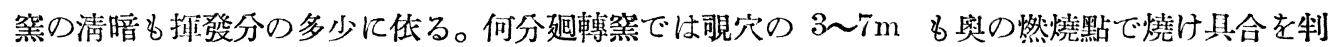

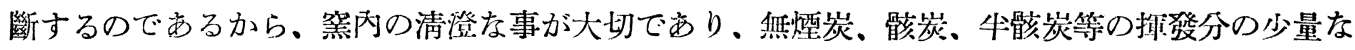
石炭が此の目的には遮合する。

其の他集中的に完全燃燒を行ひ熱效率を良好をらしめるには石炭の性質に依る事は勿論だが使 用技術の良否に關する事も大である。工場設借及熟練に依て然料の缺陷を補ひ得る場合がある故

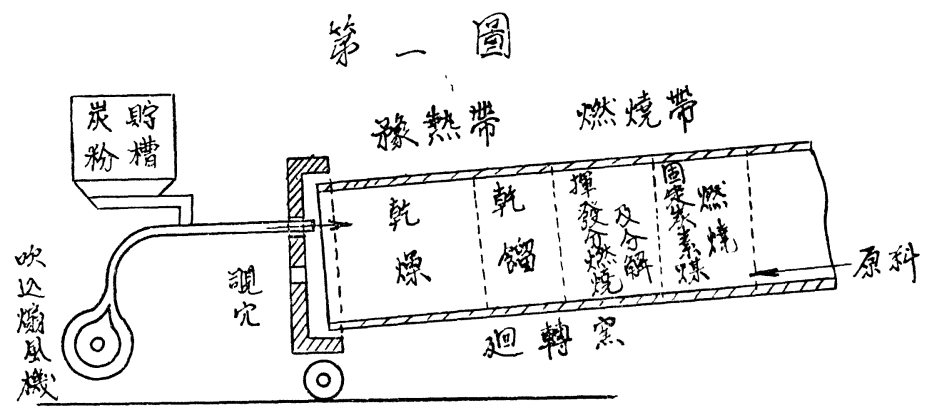

に、炭粉燃燒の賽際問題に就ても簡單に記述する必要があるcセメント燒成では第一圖に示す如

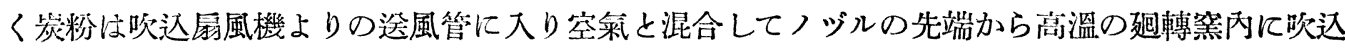
まれ、份冷却筒から吸引せられる熱空氣をも供給せられて燃燒する。燃燒狀態を仔細て考えるに

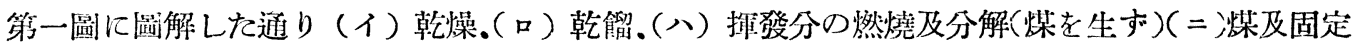
炭素の然燒の匹階程を經る。勿論此等の反應は第一圖の如く明瞭に區劃せられるものでなく重疊 して起る物である。(イ)(ロ)は通常吸熟反應であるから炭粉吹込口直前の溫度は低下寸る、(ハ) 
（二)が發熱反應で（ハ）に於ては揮發分は熱分解を受け先づ水素が燃燒し炭素 (煤)を原子狀に 遊離する、次で（ハ）の部で此の炭素及乾餾されて生じた固定炭素が燃燒を行ふ。最高の熱效率

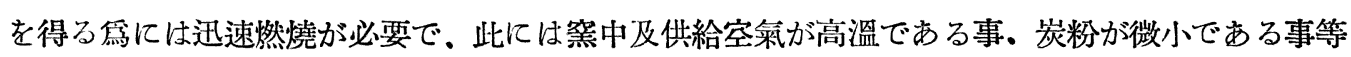
老條件とする。第一圖でも明白な如く石炭の主要成分である固定炭素が最も燃燒し難く、先づ炭 素粒子、を被覆する不活性瓦斯を除去し次で容量よりすれば數一倍にも當る宾氣を接觸させね壮を らんので、空氣中を搌散する餘裕さえあればどれ程でも速く燃燒する瓦斯體燃料とは異なり、餘 分の空莱を要する傾向のある事は事實である。從つて固定炭素含有量大なる石炭は迅速燃燒が因 難である、然し前述の通り、石炭の極微粉碎、供給空氣の高熱、空氣、炭粉の完全な混合により 吸熱反應起減じ、反つて此の方が ( ) 部に集中的の燃燒を起し得る理となる。

然燒溫度は石炭の發熱量、成分站びに過剩空氣の量に依つて定まるルーロフス氏 (Dr. W. I ulofs, Transactions of the Fuel Conf.) の『岑粉汽罐燃燒室の要素』なる論文より拔萃するに炭 粉燃燒に依る理想溫度 (T) は $T=H /\left\{Q_{\mathrm{CO}_{2}} \bullet S_{1}+\left(Q_{\mathrm{H}_{2} \mathrm{O}}+W\right) S_{2}+Q_{\mathrm{air}} S_{3}+A S_{4}\right.$ で計算出來る

$\begin{array}{ll}H & \text { 石孷の發熱量 } \mathrm{Cal} \\ Q_{\mathrm{CO}_{2}}, Q_{\mathrm{H}_{2}} \mathrm{O}, Q_{\mathrm{air}} & \text { 燃燒生成物な万 } \mathrm{CO}_{2}, \mathrm{H}_{2} \mathrm{O} \text { 及過剩空氣の重量 } \\ \mathrm{S}_{1}, \mathrm{~S}_{2}, \mathrm{~S}_{3}, \mathrm{~S}_{4} & \mathrm{CO}_{2}, \mathrm{H}_{2} \mathrm{O} \text {, 空氣, 灰分の比熱 } \\ W & \text { 石宸の化合水分 } \\ A & \text { 石炭の灰分 }\end{array}$

此の一例として次の成分を有する哭煙炭（A）と長焰炭 (B) 几就て種々の過剩空氣の場合の理 想溫度及び生成煙道瓦斯の炭酸瓦斯含有率を計算して居る。(第二圖參照)

$$
\text { 第 三 表 }
$$

$\begin{array}{lcccccccrr} & \text { 水 分 } & \text { 炭素 } & \text { 水素 } & \text { 酸 素 } & \text { 䇪素 } & \text { 硫黄 } & \text { 揮發分 } & \text { 灰 } & \text { Cal } \\ \text { (A) } & 3.31 & 88.74 & 3.43 & 1.69 & 0.72 & 0.59 & 5.31 & 1.52 & 7,971 \\ \text { (B) } & 2.55 & 71.52 & 4.03 & 7.07 & 0.99 & 1.49 & 28.08 & 12.35 & 6,981\end{array}$

赹轉筈の然燒帶の溫度は 1450 〜 $1580^{\circ} \mathrm{C}$ であるとの文獻があるから最高 $1600^{\circ} \mathrm{C}$ を要するとし ても、第二圖に低れ汪理想的燃燒の状態に於ては大抵の石炭をら差支えない事を見る。然し實際

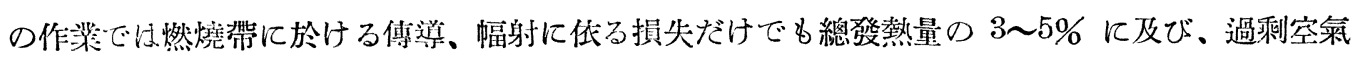
も最大 1.5 位は見て置かねばをらんから，上記の計算によると本邦炭で $6000 \mathrm{Cal}$ 以下、化合水 分 $20 \%$ 以上なる場合は不合格となる。灰分は燃燒溫度には左程惡影響を及ばさない。第二圖で B 炭の方が高溫を呈して居るのは水素の含有率が大なる爲で、水素は $1 \mathrm{~g}$ 當發熱量大なるにより高 溫然燒には有利である。又過剩空氣は如何に燃燒溫度を低下寸るか考明瞭に示して居る。高溫然 燒をする程熱勃率良き事は從前より說明した所であるが。セメント燒成の䁈際問題として餘りに 高きに失すれば燒過ぎとなり又內張りの耐火煉瓦を熔隇する事速き等の缺點ある故發熱量より言 へば 6500 7500Cal 化合水よりすると $20 \%$ を超過せ呚物が適當でする。長栬不粘結炭以下の 
褐炭亞炭等の使用は難事である事を示して居る。

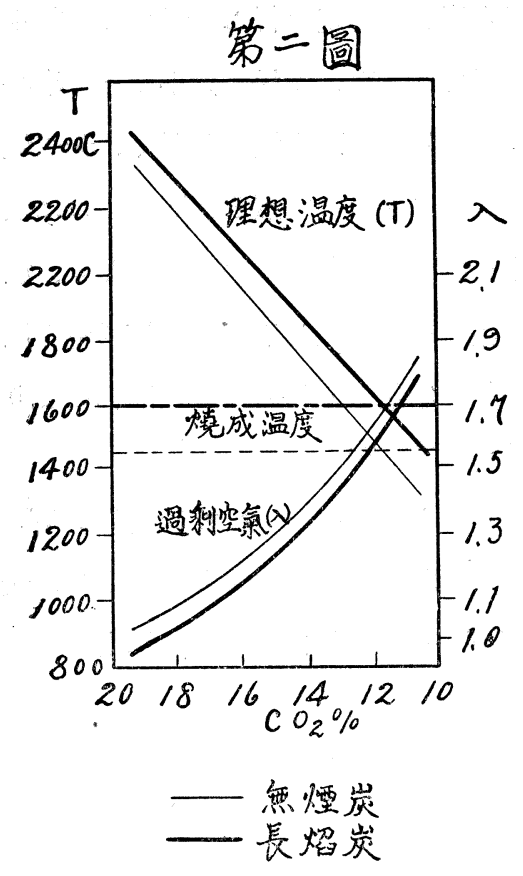

(iii) 石炭の灰分

本邦產石炭の灰分は 2 30\% で成分は主として $\mathrm{SiO}_{2}$, $\mathrm{Al}_{2} \mathrm{O}_{3}, \mathrm{Fe}_{2} \mathrm{O}_{3}, \mathrm{CaO}$ で份少量の $\mathrm{MgO}, \mathrm{TiO}_{2}$, alkali, $\mathrm{S}$ 等を含む。栗原氏 (工業化學雜誌 大正十二年) の研究 に依る本邦炭灰分の分析中第四表の比に於て セメントの 其と比較するに

\begin{tabular}{|c|c|c|}
\hline 第 & 表 & \\
\hline & 灰 分 & セメント \\
\hline $\mathrm{SiO}_{2} / \mathrm{Al}_{2} \mathrm{O}_{3}$ & $0.92 \sim 1.58$ & $3.8 \sim 4.5$ \\
\hline $\mathrm{Al}_{2} \mathrm{O}_{3} / \mathrm{Fe}_{2} \mathrm{O}_{3}$ & $0.58 \sim 6.2$ & $1.5 \sim 2.3$ \\
\hline $\mathrm{CaO} / \mathrm{SiO}_{2}+\mathrm{R}_{2} \mathrm{O}_{3}$ & $0.08 \sim 0.52$ & $2.00 \sim 2.20$ \\
\hline （附）熔融點微 & S.K 3 $>10$ & S.K. $25(?)$ \\
\hline
\end{tabular}

第四表で石炭の灰分及七メントの成分比を比較したが 兩者間には大差が每り、叉一般に灰分はセメントよりは 熔融點が低い。セメント燒成の特牲の項でも述べた通り。 灰分の一部は燒塊と共融し、又は原料と混じ何れもセメ

ントの成分に變化を來し、侗廢熱汽罐又は集鹿機等で沈澱可收せられ殘部は煙突から飛散する。

セメント成分に及济す影響は（イ）水硬率の低下(口)硅酸攀土比乃至は硅酸率の低下であつて、 通氣による原料の飛散と共にセメント燒成中成分變化を起す双壁で、豫め此等の變化を見越して 原料調合を行つて居る。從つて石炭郎灰分を突然變更する事は面白くなく、燒成困難を感じた場 合灰分少量な高級炭を使用し一層不結果に索る事がある。灰分は燒塊ひいてはセメントの色合に 影響する。明膫な說明は不能であるが硅酸多く硫黄少量の場合セメント特有の綠灰色を呈する樣 である。

廢熱汽罐の据付けられた工場では灰分の融着性及び應蝕性を考虑せをければならぬ事は他の炭 粉然燒汽罐と異る所はない。

虔熱汽䚭瓦斯入口での溫度は $800 \sim 1000^{\circ} \mathrm{C}$ であるから大抵の灰分は融着する危險はないが、 何分セメント原料も共に飛散を起すのであつて其の中の石灰、硅酸等が混合すれば極く低溫で熔 融する共融物を生ずる。此がセメントの廢熱を利用する際の根本的の缺陷であつて、水管伤附着 した粉塺の除去及び休罐掃除を頻繁に勵行せをければ熱傳導率を著しく減少する椂になる。其で 灰分の耐火度は可及的高い事を希敁するが此れのみでは安心ならず石灰硅酸等と共融物を作る點 をも考虑せなければならぬ。

鹰蝕性につレては何分他の汽罐に比して低溫な爲に餘り問題とする程つ事は無い。 
セメントエ場よりの粉嶎が社會問題を惹起した事は既に久しく、各社は概ね收塵裝置を探用す るに至つた。粉塺發散の大宗である伵轉窯にあつては廢熱汽罐を排出し比較的低溫となつた瓦斯 をサイクロン・氷洗機・コツトレル等の收塵機に通じるのであるが、飛塵粒子の大きさは 10-2〜 $8 \times 10^{-5} \mathrm{~cm} \varphi$ で斯の範圍では微小となる程捕え難い事は第五表の如くであるが、高溫で然燒した 石炭よりの灰分が最も微小であるから、當問題からしても厄介なのは灰分である。

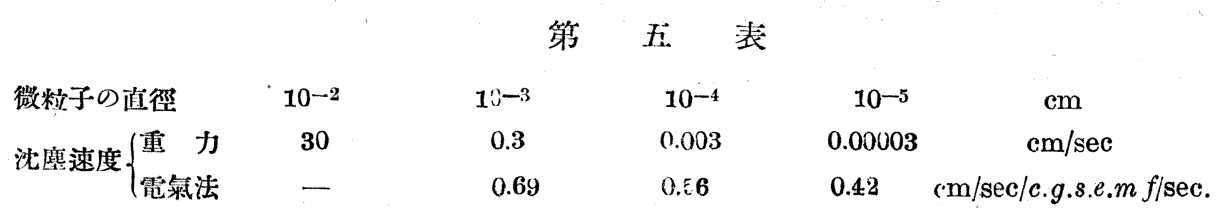

灰分は多くとも炭化の程度進行した良質の石炭を使用したきはセヌント工業者の希整でばある が上述した種々の第二義的の事情にてばまれる故ミーデェ氏の價格のゆるす限り灰分少なき石炭 を使用する點に同感であるが事情の許す限り灰分多くとも格安の石炭を用ふる事は石炭の合理的 使用の問題よりし、ても意味ある事である。

(iv) 石炭の自然發火性

乾燥機老排出する石炭は 70〜 $100^{\circ} \mathrm{C}$ 几熱せられて居り、此を粉碎し空氣選別する事とて、自 然發火內徑は炭塵爆發の機會は隨處に存し此に關する炎害も屡耳にする故に自然發火の性質は重 大な問題である。此の不炭の自然性に關する研究は九大の稻葉・宮川・山田の三氏（九州帝國大 學彙報）に依り徽底的に行はれて居る。概要老記するに本邦及滿洲の代表的の石炭 70 餘種を探 り酸化に依る溫度上景老测定し、此の溫度上昇の急激なる目尾、忠隈。鯰田、新原、大辻。上山田、豐 國、小野田。方城等の不炭は現場に於ても自然發火の經驗ある事上り、酸化に上る溫度上景の早き 石岑は自燃性老有すと言はれる。然し天草旭炭、平壤無煙炭は例外で自燃性考有すに係ら晾試驗 結果遲く出て居る。其の他自然性の本質及防止策等に就て詳說してむる。

\section{IV 結 論}

以上諭述した所に依ると甲の條件に適當な物は乙の條件には不合格であつたりして、理想的の 物は求め難い事が明白になつた。其で工場の性質に依り、地方的の狀況によつて管理者が適宜考 慮按排すべき問題で著者一個の考へより結諭する事は暴舉であるが、意見を一絿にして記载すれ ば

（1）石炭の贌入にあたつては水分は勿論、乾燥用炭の價格も引去つた單位熱量當りの價格を 標準とすべきであつて、炭粉燃燒をなすセメント工場では格安なる粉炭・微粉炭が有利であるか ら、此等の使用に差支えなき樣最初から設計すべきである。

（2）濕分及化合水分は炭種に依るのであるから引合の時又は納入の場合工業分析の他に水分 
の試驗も重大視せなければをらぬ。濕分 5\%を越え、アソーブス試驗による水分 $20 \%$ 以上の石 炭は一考を要する。

（3）揮發分は從來重大要件に考へられて居たが、機栈・設借の整供した現今ではを左まで重要 でなく、無洷燃料の混用も可能であり吹込炭として揮發分 $10 \%$ 以上西れば差支えなし。

（4）固定岑素多き石炭は種々の利點を有するが、燃燒速度が僬く過剩空氣を多量に要し癷で あるから、石炭の微粉碎、空氣との混合、空氣の豫熱が必要である。

（5）熱効率上き高溫燃燒を行ふには、石炭は發熱量高く、水分少なく、㕛酸素少なき事を要 する。

（6）灰分は吹込燃燒では熱損失の方では大なる害はないが、セメント品質を低下させ、廢熱 汽罐の能率を害し、其の飛塵は捕勧しがたく社會問題をも誘發する事あれば、價格のゆるす限り 少量をる事を希胵する。

（７）自然發火性の少ないるのを撰擇する事

以上の所說に於て業者の參考となり、研究家に何等か暗示を與へるの誘引ともならば幸でらる。 （昭和五年七月五日受理）

\section{セメント工業に於ける動力と熱の經濟 (承前)}

(Jakob Koch, Zement, Nr. 14-18, 1930)

\section{$\mathbf{T} \mathbf{Y}$ 生 譯}

\section{廢瓦斯の温度}

第四圖は乾式及濕式に於ける廢瓦斯の溫度と瓦斯中の䫘熱との川の關係を示す。

乾式及濕式の廢瓦斯量と含有熱量との比較は第蕒圖及第參圖に示したが乾式の場合洁廢瓦斯量 が少いに不拘含有熱量は濕式に於けるよりも却而多い。

乾式の廢瓦斯量は $2.87 \mathrm{Cbm} / \mathrm{kg} . \mathrm{cl}$ にて顯熱量は $1020 \mathrm{Cal} / \mathrm{kg} . c \mathrm{~s}$ 第式にては $4.54 \mathrm{cbm} / \mathrm{kg} . \mathrm{cl} に$ て同じく $900 \mathrm{Cal} / \mathrm{kg} . c 1$ なり。

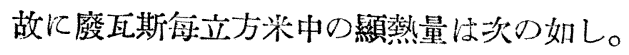

乾式 : $\frac{1020}{2.87}=356 \mathrm{Cal} / \mathrm{cbm}$

濕式 : $\frac{900}{4.54}=198 \mathrm{Cal} / \mathrm{cbm}$ 